PSICOLOGIA,SAÚDE \& DOENÇAS, 2017, 18(1), 1-18

ISSN - 2182-8407

Sociedade Portuguesa de Psicologia da Saúde - SPPS - www.sp-ps.com

DOI: http://dx.doi.org/10.15309/17psd180101

\title{
SPONTANEOUS SELF-CONCEPT IN A SUCCESSFUL WEIGHT LOSS - A PLURALIST QUALITATIVE STUDY
}

\author{
Raquel Rosas ${ }^{1}$, Filipa Pimenta ${ }^{1{ }^{\circledR}}$, João Maroco $^{1}, \&$ Isabel Leal $^{1}$ \\ ${ }^{1}$ William James Center for Research, ISPA - Instituto Universitário; Lisboa, Portugal; e-mail: rrosas @ ispa.pt; e-mail: fili- \\ pa_pimenta@ispa.pt; e-mail: ipmaroco@ispa.pt; e-mail: ileal@ispa.pt
}

\begin{abstract}
Obesity implies risks for physical and psychological health, impacting negatively on self-esteem. As an improvement strategy, weight loss often has an impact not only on body image but also on others domains of self-concept. Despite the extensive research on physical self-concept, the exploration of others self-concept's domains concerning a weight loss is scarce. This study aims to explore the spontaneous self-concept of a successful weight loss. Thirty men and women who achieved a successful weight loss (loss at least $7 \%$ of the initial weight and made a minimum maintenance of 12 months) were interviewed. The in-depth audio-recorded interviews were transcribed and analysed through content and thematic analysis (pluralistic analysis with inductive and deductive approaches), by a jury of psychologists. A quantitative exploration of the association between the emergent categories was made through a multiple correspondence analysis. An inter-rater agreement (Cohen's k) was substantial (.734). Self-concept established a three-factor model: 1) Effective investment/Balanced self-esteem, 2) Ambivalent, and 3) Positive acceptance/Focused, entailed domains such as self-esteem, physical, social, and explicit personality self-concept. The qualitative exploration of self-concept on a weight loss context contributes to engrossing the current literature. Emphasising that not only physical but also psychological aspects may be impacted in a successful weight loss process, this study highlights that negative self-representations must be attended in a clinical interventions' context.
\end{abstract}

Keywords: Successful Weight Loss, Self-Concept, Qualitative, Content Analysis, Thematic Analysis

\section{AUTO-CONCEITO ESPONTÂNEO NUMA PERDA DE PESO BEM-SUCEDIDA- ESTUDO QUALITATIVO PLURALISTA}

RESUMO: A obesidade implica riscos para a saúde, afectando negativamente a auto-estima. Como estratégia de melhoria, a perda de peso impacta não só a imagem corporal como também outros domínios do auto-conceito. Apesar da extensa investigação sobre o autoconceito físico, a exploração de outros domínios do auto-conceito relativamente a uma perda de peso é escassa. Este estudo tem como objectivo explorar o auto-conceito espontâneo de uma perda de peso bem-sucedido. Trinta homens e mulheres que fizeram uma perda de peso bem-sucedida (perda mínima de 7\% do peso inicial e uma manutenção mínima de 12 meses) foram entrevistados. As entrevistas foram gravadas em audio, transcritas e analisadas através da análise de conteúdo e análise temática (análise pluralista com abordagens indutiva e

\footnotetext{
Rua Jardim do Tabaco, 34, 1149-041 Lisboa, Portugal. Telf.: +351 218811700; e-mail: filpa_pimenta@ispa.pt
} 


\section{SELF-CONCEPT IN WEIGHT LOSS: QUALITATIVE STUDY}

dedutiva) por um júri de psicólogos. A exploração quantitativa da associação entre as categorias emergentes foi feita através de análise de correspondência múltipla. Um acordo entre avaliadores ( $\mathrm{K}$ de Cohen) foi substancial (.734). $\mathrm{O}$ auto-conceito estabeleceu um modelo tri-factorial: 1) Investimento eficaz/Auto-estima equilibrada, 2) Ambivalência, e 3) Aceitação positiva/Foco, que incorporaram domínios como a auto-estima, auto-conceito físico, social, e de personalidade explícita. A exploração qualitativa do auto-conceito num contexto de perda de peso contribui para o aprofundamento da literatura. Realçando que aspectos físicos e psicológicos podem ser afectados numa perda de peso com sucesso, este estudo destaca que as auto-representações negativas devem ser consideradas em contextos de intervenção clínica.

Palavras-chave: Perda de Peso, Auto-conceito, Qualitativo, Análise de Conteúdo, Análise Temática

Recebido em 09 de Novembro de 2016/ Aceite em 27 de Novembro de 2016

As medical conditions of major significance, overweight and obesity can increase the risk of multiple physical illnesses. Main examples are cardiovascular disease, coronary heart disease, hypertension, type II diabetes, sleep apnea, musculoskeletal issues and some types of cancer (Anderson \& Konz, 2001; Sarwer, Dilks, \& Spitzer, 2011; Stroebe, 2008). Identified as critical health issues, overweight and obesity not only have impact over physical health, but also affect individuals' psychological state (Fabricatore et al., 2011; Ogden \& Clementi, 2010; WHO, 2015). These physical conditions exhibit a high association with social stigmatisation, discrimination and prejudice (Stroebe, 2008). According to Ogden and Clementi (2010), overweight or obesity have impact on personal domains such as the individual's mood, self-identity and self-perception, relating the weight to a feeling of dissociation with one's body. Previous research (Harris, Harris, \& Bochner, 1982; Hebl \& Mannix, 2003; Ogden \& Clementi, 2010) reported that people who have overweight or obesity are frequently perceived by others as less intelligent, less capable of achieving success, lacking attractiveness, unpopular, lazy, and self-permissive.

Furthermore, the literature (Crandall \& Biernat, 1990; Ogden \& Clementi, 2010; Stroebe, 2008) also indicates that comments, expectations and overall attitude of others about the weight of individuals with obesity have impact on their self-perception, self-identity and self-esteem, in addition to influence their experience as having obesity. People with overweight who refer a history of stigmatisation tend to report a higher dissatisfaction with their bodies, higher levels of distress, a more dysfunctional investment in their appearance, and a more negative body image (Annis, Cash, \& Hrabosky, 2004; Latner \& Wilson, 2011).

Recognised as a significant approach to health improvements (Vidal, 2002), weight loss can help preventing coronary heart disease, reducing cardiovascular risk factors, and benefiting the treatment of type II diabetes (Anderson \& Konz, 2001; Vidal, 2002). The positive outcomes of a moderate weight loss of 5 to $10 \%$ of the initial weight have been well established, being associated with improvements on systolic and diastolic blood pressure, lipids and glycaemia levels, and efficient in preventing the manifestation of type II diabetes and hypertension in overweight individuals (Vidal, 2002; Wing et al., 2011). A "successful" weight loss highlights not only the weight reduction but also transformations in health-related behaviours. Success in weight decrease has been defined as an intentional weight loss (Wing 
\& Hill, 2001) equal or beyond 7\% of the initial weight (Knowler et al., 2002), maintained for at least 12 months (IOM, 1995).

However, a successful weight loss isn't exclusively related to positive sequels. Gorin and colleagues (2007) described that weight loss related changes often fail to live up to one's expectations. Empirical evidences also indicate unwanted increase of attention by others (Annis et al., 2004) and undesirable body changes (Sarwer et al., 2011) as consequences for individuals who went through weight loss. Moreover, patients who undergo bariatric surgery report dissatisfaction with their body image correlated with sagging, flaccid skin in different body areas such as breasts, arms, abdomen and thighs (Sarwer et al., 2011).

Weight loss encompasses several changes linked to physical, psychosocial and psychological features of the individual (Sarwer at al., 2011). Therefore, it's pertinent the study of its association with other dimensions that are included in one's self - specifically, the individual's self-concept, in order to understand the person's self-perceptions in multiple domains, in a weight loss context.

\section{Spontaneous Self-Concept}

The self can be understood as a cognitive representation of a complex structure, which assists in the organisation of relevant self-knowledge (Linville, 1985). According to Baumeister (2010), it is possible to enunciate three basis of the self: 1) the overturn of the consciousness towards itself, identified as the awareness and knowledge a person has about oneself; 2) interpersonal relationships, since the self is emerged in reciprocal relations with others and has the function (between many others) of nourishing those relations; 3 ) decisionmaking and exercising control.

Oyserman, Elmore and Smith (2012) defined self as the aggregation of a thinking agent ("I think") and an object of that contemplation ("about me"). Furthermore, the authors point out that in the content of that object resides mental concepts that particularly designate who one was, is, and will become - those mental notions are entitled self-concept. Through the interaction with the environment, the individual produces beliefs and self-perceptions about oneself that are influenced and reinforced by the appraisals of significant others and by the person's own behaviour (Baumeister, 2004; Schunk \& Pajares, 2009; Shavelson \& Bolus, 1982).

Organising one's process of information (Markus, 1977), the self-concept's structure allows not only the categorisation of knowledge but also the communication between those categories (Shavelson \& Bolus, 1982). When referring to its structure, is possible to affirm that the self-concept is multidimensional (Shavelson \& Bolus, 1982). Several distinct evaluative judgments of personal attributes are distributed through discrete domains (Harter, 2008). This multidimensional approach allows the explanation of the different self-evaluation people do about themselves in different domains of their self-concept (Harter, 1999). These multiple domains - also designated as schemas, self-schematas (Markus, 1977), categories, or aspects (Linville, 1985) - reflect the relevant knowledge an individual has about a particular personal trait or attribute (Crisp \& Turner, 2010). Regarding the diversity of dimensions that a global self-concept can involve, it's expected that the number of selfschemas echoes the number of roles one has in life - e.g. student, friend, parent, etc. According to Linville (1985), a person conceptualises oneself in numerous ways concerning broader experiences in particular roles, behaviours, relationships, and others. Shavelson and 


\section{SELF-CONCEPT IN WEIGHT LOSS: QUALITATIVE STUDY}

Bolus (1982) established two broad classes concerning the self-concept structure - 1) academic self-concept and 2) non-academic self-concept - where the non-academic selfconcept is sectioned into social, emotional and physical domains. Particularly, the physical domain is further differentiated between physical ability and physical appearance.

The discrete domains can acquire specific qualities since they depend on lived experiences. In addition to the enumeration of some schemas that can compose self-concept - such as cognitive competence, physical appearance, self-esteem, social acceptance, and others - Harter (2008) designated further domains as domain-specific self-evaluation, enabling the customisation of an individual's self-schema and one's self-concept. A person can also identify self-perceptions that describe one's personality, characterising personal, relatively stable and non-pathological traits - designated as explicit personality self-concept (Asendorpf, Banse, \& Mücke, 2002; Schnabel, Asendorpf, \& Greenwald, 2008). Oyserman, Elmore, and Smith (2012) structured self-concept considering the multiple perspectives one can view oneself from. They established the a) individualistic "me" self or the collectivistic "us" self, b) distal "future" self or temporarily "now" self, and c) immersed "mind's-eye" self or the observer's "eye of others" self.

Despite the feature of stability associated with this psychological construct, the structure of self-concept can also be characterised as large, dynamic and complex (Baumeister, 2004). The several dimensions that constitute a person's self-concept oscillate on one's thought at different times. Baumeister (2004) designated as spontaneous selfconcept the specific domain of self-concept present at one's mind, in a particular moment. Therefore, the spontaneous self-concept changes, even though self-esteem and others deeper facets of self-concept appear to resist variations.

The study of people's self-concept in the ambit of physical health has major importance, since different domains of one's life are affected when the person's health is threatened. Rojas, Brante, Miranda and Pérez-Luco (2011) explored the self-concept on people with morbid obesity submitted to bariatric surgery. According to the authors, the participants reported increased feelings of attractiveness and satisfaction, also affirming that they felt more secure, agile, and accepted. Gender differences were also explored by Marčič and Grum (2011), where females showed a better overall self-concept, being more satisfied with themselves in the relationship domain, with partners, family, and social context. In this study, men and women indicated to be equally satisfied with individual domains, such as appearance, physical fitness, and intelligence.

When investigating the association between one's weight status and their physical self-concept, Binkley, Fry and Brown (2009) establish that both men and women who perceived they were at a normal weight reported a significantly higher score physical selfconcept than those who perceived themselves with overweight or obesity. Like many other domains that may compose one's self-concept, the physical self-concept - which includes body image - hasn't been explored in the field of weight loss.

\section{Body Image}

The body image considers the subjective perceptions, beliefs, attitudes and behaviours the individual has about his/her body, being a multidimensional psychological construct (Cash, 2004, 2011). According to the author $(2004,2011)$, it is possible to identify two main core axis comprehended by body image - i) the attitudinal axis, that includes an evaluative and the investment components, and ii) the self-perception axis. Regarding the attitudinal 
frame, the a) evaluative component mentions the quality of the satisfaction a person has with one's appearance, the beliefs about one's appearance and possible self-ideal discrepancies (Cash, 2004, 2011), and the b) investment factor states the degree of cognitive, emotional, and behavioural importance that one assigns to the body's self-evaluation (Cash, 2004, 2011).

These two basic body image attitudes - evaluation and investment - are constructs with organisational capabilities in cognitive, behavioural, and emotional processes happening in contextual events (Cash, 2011). Particularly, the body image investment implicates specific self-schemas a person develops related to one's appearance. Cash, Melnyk, and Hrabosky (2004) accentuate the appearance-related self-schemas that body image investment comprehends. Because self-schemas develop according the multiple domains within the person (Markus, 1977), contextual experiences trigger one's appearance-related schema to process self-evaluative relevant information about the individual's body (Cash, 2011; Cash, Melnyk, \& Hrabosky, 2004). Consequently, the study of those appearance-related selfschemas is essential when trying to understand an individual's body image experiences.

Both genders face, nowadays, unrealistic body standards that might damage one's welfare - these exaggerated body image goals prompt women's ambitions for extreme thinness and men's drive for extreme investment in muscularity (Murnen, 2011). Negative body image investment has also been demonstrated to affect differently according to the gender (Pritchard, 2014). In this ambit, women report a higher concern with the level of body fat (Charnyak \& Lowe, 2010), while men tend to be more worried not only with body fat but also with the muscularity level (Jung, Forbes, \& Chan, 2010).

People with overweight and obesity also showed dissatisfaction with their bodies and appearances. Besides reporting dissatisfaction with one's size and weight, people with these conditions indicate dissatisfaction with distinct body traits (Sarwer at al., 2011). In fact, health improvement and risk reduction for health-related problems are not the major motive pointed by people as the motivation to weight loss; most individuals express physical appearance improvement as the main motivation (Sarwer at al., 2011).

The body image can be understood as a psychological construct that comprises one's self-concept, the self-perception of the body and appearance, and the perceived feelings towards the person's body (Alipoor, Goodarzi, Nezhad, \& Zaheri, 2009), which supports the pertinence of exploring the self-concept on individuals that have experienced a weight loss process.

Therefore, the present study aims to explore the spontaneous self-concept of men and women who have made a successful weight loss, through a pluralistic qualitative approach (both content and thematic analysis).

\section{METHOD}

\section{Participants}

A non-probabilistic convenience sample included 30 Portuguese individuals (15 men and 15 women), with an average age of 43.69 years $(S D=13.24)$, an average weight loss of $25.02 \%(S D=13.85)$, and a mean BMI of $29.70 \mathrm{~kg} / \mathrm{m}^{2}(S D=6.84)$. The most frequent weight loss method (Table 1) was the change of eating habits (33\%) followed by dietary changes combined with physical exercise (20\%) and bariatric surgery (17\%). 
The inclusion criteria were i) 18 years or older, ii) minimum literacy and being able to answer an extensive and audio-recorded interview, iii) have a weight loss equal or above $7 \%$ of the initial body weight, and a minimum of 12 months of weight maintenance.

Table 1.

Frequencies and Percentages of Socio-demographic Characteristics

\begin{tabular}{ccc}
\hline Socio-Demographic Characteristics & Frequency & Percentage \\
\hline Affective-Sexual Relationship & 17 & \\
Yes & 11 & 60.7 \\
No & & 39.3 \\
\hline Number of Children & 9 & \\
0 & 5 & 37.5 \\
1 & 6 & 20.8 \\
2 & 2 & 25 \\
3 & 1 & 8.3 \\
4 & 1 & 4.2 \\
5 & & 4.2 \\
\hline
\end{tabular}

Physical Exercise Practice

No

9

Yes

17

65.4

Recent Disease

No

19

70.4

Yes

8

29.6

Recent Psychological Problem

No 20

Yes

7

25.9

Educational Level

Incomplete Primary School (4 years or less)

Primary School (6 years)

Middle School (9 years)

High School (12 years)

Bachelor (3 years in College)

Graduate (5 years in College) 
Raquel Rosas, Filipa Pimenta, João Maroco, \& Isabel Leal

\begin{tabular}{lcc} 
Master (7 years in College) & 1 & 3.7 \\
Other & 1 & 3.7 \\
\hline Annual Household Income & 6 & 20 \\
$10.000 €$ or less & 11 & 36.7 \\
From 10.001€ to $20.000 €$ & 4 & 13.3 \\
From 20.001€ to 37.500€ & 3 & 10 \\
From 37.501€ to 70.000€ & 1 & 3.3 \\
Superior to 70.001€ & & 18.5 \\
\hline Weight Loss Methods & 5 & 37 \\
Surgery & 10 & 3.7 \\
Change in Eating Habits & 1 & 3.7 \\
Physical Exercise & 1 & 22.2 \\
Surgery and Change in Eating Habits & 6 & 3.7 \\
Change in Eating Habits and Physical Exercise & 1 & 7.4 \\
Surgery, Change in Eating Habits and Physical Exercise & 2 & 3.7 \\
Change in Eating Habits and Other* & 1 & \\
Surgery and Other* & & 1 \\
\hline
\end{tabular}

*Other methods include walks and the intake of natural supplements. 


\section{SELF-CONCEPT IN WEIGHT LOSS: QUALITATIVE STUDY}

\section{Materials}

A questionnaire was given to the participants to assert socio-demographic characteristics (ex., age, sex, marital status, educational level), physical exercise (e.g., Do you practice any physical activity?, If so, how many times per week?), health status - including psychological health (e.g., have you recently had any psychological problem?) and physical health (e.g., have you recently had any disease?). A computer with an attached microphone was used to allow the audio-recording.

The semi-structured interview protocol was applied in order to obtain personal descriptions of experiences within the process of weight loss, addressing the spontaneous nature of one's self-concept not only through the perspective of the immersed "mind's-eye" self but also through the observer's "eye of others" self (Oyserman et al., 2012). The protocol entailed the following questions:

(1)How do you think the people you know (those with whom you don't have a close relationship) see you currently?

(2)And the people closest to you?

(2.1) How do you think your family sees you?

(2.2) How do you think your friends see you?

(1)And how do you see yourself? How would you describe yourself? How do you evaluate yourself regarding your personal features?

\section{Procedure}

The established contact with the participants took place between September of 2012 and June of 2013. The data was assembled in clinical, hospital and private practice settings, in addition to social networks (Facebook, e-mail contact) and participants referencing (snowball sampling).

All participants received an informed consent and signed a written permission allowing the audio-recorded interview. Interviews were made personally or by telephone, according to the participant's availability. The gathered data was fully transcribed, including audible and non-verbal content, such as pauses and laughs.

The data collected from the semi-structured interviews was transcribed and analysed through content and thematic analysis (Bardin, 1977; Braun \& Clarke, 2006). The content analysis followed the recommendations of Bardin (1977), and the exhaustivity and exclusivity criteria, with the purpose of acquiring objective, systematic and quantitative descriptions of the manifest content. The thematic analysis enabled the identification, exploration and description of patterns or themes within the gathered data (Braun \& Clarke, 2006). The combined content and thematic analysis enabled i) an inductive approach, since the manifested data allowed the identification of themes, prompting its coding and enumeration, and ii) a deductive approach, considering the theory-driven analysis of the emergent themes. In the present methodology, it was privileged a coding process which didn't force any data into a pre-existing coding frame or theoretical attribute, meaning it prevailed the participant's manifest content as the most significant data to identify.

The representation of the subcategories was made through a frequency and percentage study. Lastly, a multiple correspondence analysis (MCA) was performed aiming to generate 
an explanatory model of the inherent construct. The descriptive analysis and the explanatory factor model were developed using SPSS (v. 22).

\section{RESULTS}

\section{Inter-Rater Reliability}

The analysis of the agreement between the researchers (or observers) is employed as a quality indicator of the designated categories and the raters' competence to apply the same (Warrens, 2014). The used coefficient - Cohen's kappa - is adapted for a two raters study and a nominal scale (with two or more categories), ranging from -1 to 1 , considering that 1 represents a perfect agreement (Cohen, 1960; McHugh, 2012). In order to assess the reliability in the present study, the two researchers coded the same pair of transcribed interviews independently. Based on both researchers' analysis, with the developed codification grid from the previous analysis of the remaining 28 interviews, the reliability assessment indicated a substantial agreement $(\mathrm{K}=.73)$.

\section{Spontaneous Self-Concept}

In the analysis of the spontaneous self-concept, multiple categories emerged when it was asked to the individual about how he/she thinks others - acquainted without a close relation, family and friends - see him/her and how the person sees oneself.

The first category referring to the self-concept - physical self-concept comprehended both an evaluative domain (emergent negative, positive and ambivalent/neutral categories) and a body/appearance investment domain. Regarding the physical appearance, the physical self-concept comprised how one sees oneself from a bodily perspective.

The negative physical self-concept involved the characterisation of specific body areas (such as the abdomen and the face), undesirable features (encompassing flaccid skin, cellulite and bone protuberance), overall dissatisfactory appearances (such as looking ill, having an overweight image or an excessively thin image), and non-specific negative physical evaluation.

The positive physical self-concept concerned overall pleasing appearances (such as looking younger and having a more toned body) as being elegant, beautiful, healthier, and also a non-specific positive physical appraisal.

The ambivalent/neutral category encompassed contents where a person showed ambivalence or neutrality towards his/hers body/image after the weight loss process.

The body investment category, comprehended in the physical self-concept, involved any demonstration of one's set of particular efforts that, deliberately or not, had an effect on physical shape or image.

The category related to physical capability of the spontaneous self-concept physical ability self-concept — only had an emergent positive valence, concerning one's personal assessment as having higher mobility and being physically active.

Other self-concept category was the interpersonal self-concept, referring one's evaluation regarding its interpersonal experiences. Having only emerged a positive valence, it 


\section{SELF-CONCEPT IN WEIGHT LOSS: QUALITATIVE STUDY}

involved seeing oneself as supportive, sociable, pacifist, making emotional investments and easily coexisting with others.

The explicit personality self-concept concerned propositional categorisations that combine other concepts of the self and personality describing attributes. In this field, both negative and positive valence emerged throughout the analysis. The negative explicit personality self-concept incorporated attributes such as distrust/suspicion, negligence/laziness, passivity/dependence, absence of willpower, self-destructiveness, vulnerability, neediness and features of unaccomplishedness. The positive explicit personality self-concept encompassed qualities as calm, less irritability and temperamental, persistence, energy, optimism, emotionality, considerate, self-defensive and efficient.

Lastly, the self-esteem was also identified as an emergent category of the selfconcept, expressing a global self-esteem domain referred to the affective and evaluative dimension of the self-concept without a specific ambit.

The frequencies concerning the acquired results of the spontaneous self-concept in a successful weight loss are presented in Table 2.

As criteria, only categories mentioned by a minimum of 3 participants (which represent $10 \%$ of the sample) were considered.

Table 2.

Frequencies and Percentages of the Spontaneous Self-concept of a Successful Weight Loss

\begin{tabular}{|c|c|c|c|}
\hline Category & Subcategory & $\begin{array}{l}\text { Subcategory } \\
\text { Frequency }\end{array}$ & $\begin{array}{l}\text { Subcategory } \\
\text { Percentage }^{1}\end{array}$ \\
\hline Ambivalent/Neutral physical self-concept & - & 15 & 50 \\
\hline \multirow{3}{*}{ Negative physical self-concept } & Overweight & 7 & 23.3 \\
\hline & Ill & 3 & 10 \\
\hline & $\begin{array}{l}\text { Excessive weight } \\
\text { loss }\end{array}$ & 3 & 10 \\
\hline \multirow{2}{*}{ Positive physical self-concept } & Skinnier/Less fat & 10 & 33.3 \\
\hline & Healthier & 4 & 13.3 \\
\hline Appearance and body investment & - & 9 & 30 \\
\hline Positive interpersonal self-concept & - & 3 & 10 \\
\hline Global self-esteem & - & 3 & 10 \\
\hline \multirow{3}{*}{ Positive explicit personality self-concept } & Calm & 3 & 10 \\
\hline & Persistent & 3 & 10 \\
\hline & Efficient & 8 & 26.6 \\
\hline Negative explicit personality self-concept & - & 4 & 13.3 \\
\hline
\end{tabular}

${ }^{1}$ Percentage of participants who mentioned the category/sub-category, considering the total sample $(n=30)$. 
For the MCA, categories featuring non-specific qualities of the self-concept in a given domain (e.g., non-specific positive physical appraisal) weren't included in the representative model since it didn't contribute to the purpose of exploring explicit features of the selfconcept of a successful weight loss. The results of the MCA for the spontaneous self-concept are shown in Table 3.

Table 3.

Three-dimensional Model of the Spontaneous Self-concept in a Successful Weight Loss

\section{Factors}

Spontaneous Self-concept
Effective Investment/

Balanced Self-esteem
Positive

Ambivalent Acceptance/ Focused

Average

\begin{tabular}{|c|c|c|c|c|}
\hline Ambivalent/Neutral physical & .13 & .17 & .01 & .10 \\
\hline \multicolumn{5}{|l|}{ Negative physical } \\
\hline Overweight & .19 & .02 & .32 & .18 \\
\hline Ill & .27 & .36 & .03 & .22 \\
\hline $\begin{array}{l}\text { Excessive weight } \\
\text { loss }\end{array}$ & .23 & .42 & .03 & .23 \\
\hline
\end{tabular}

Positive physical

\begin{tabular}{|c|c|c|c|c|}
\hline Skinnier/Less fat & .09 & .20 & .01 & .10 \\
\hline Healthier & .00 & .12 & .11 & .08 \\
\hline Appearance and body investment & .15 & .09 & .02 & .09 \\
\hline Positive interpersonal & .15 & .50 & .03 & .23 \\
\hline Global self-esteem & .41 & .01 & .03 & .15 \\
\hline \multicolumn{5}{|l|}{ Positive explicit personality } \\
\hline Calm & .09 & .05 & .49 & .21 \\
\hline Persistent & .08 & .00 & .42 & .17 \\
\hline Efficient & .24 & .04 & .00 & .09 \\
\hline Negative explicit personality & .30 & .21 & .13 & .21 \\
\hline Eigenvalue & 2.32 & 2.19 & 1.60 & 2.04 \\
\hline Variance explained by factors $(\%)$ & 17.88 & 16.83 & 12.29 & 15.67 \\
\hline
\end{tabular}




\section{SELF-CONCEPT IN WEIGHT LOSS: QUALITATIVE STUDY}

\section{DISCUSSION}

This study explored the spontaneous self-concept of a successful weight decrease. The domains of the spontaneous self-concept found were the following (from the most to the least referred): i) physical self-concept, ii) interpersonal self-concept (only the positive valence), iii) explicit personality self-concept, and iv) global self-esteem. The most commonly mentioned domain concerned physical self-concept, with the category of ambivalent/neutral physical self-concept $(n=15)$; this emphasises the transformation not only of one's body but also of the person's appearance perception, related to a sense of strangeness regarding the physical self. This meets the literature, considering the evidence of a shift in the individual's self and the unfamiliarity of the perceived body following a weight loss (Epiphaniou \& Ogden, 2010; Gilmartin, Long, \& Soldin, 2013; Nascimento, Bezerra, \& Angelim, 2013).

The i) physical self-concept comprehends emergent categories from positive and negative valences, as well as the ambivalent/neutral ambit and the appearance and body investment domain. This emergent content concerning one's body image and physical selfconcept is sustained by Cash et al. $(2004,2011)$ theory, since it comprehends both the individual's self-perceptions and attitudes (through evaluation and investment) about the one's concept ("How do you see yourself? How would you describe yourself? How do you evaluate yourself regarding your personal features?").

The positive physical self-concept encompassed as most mentioned sub-categories a skinnier/less fat appearance and a healthier physical image. Several studies regard healthrelated positive self-evaluations after weight loss (Alegría \& Larsen, 2015; Annesi \& Porter, 2015; Gilmartin et al., 2013). A skinnier perceived self is linked with satisfaction since it mirrors a feeling of self-realisation (Nascimento et al., 2013).

The negative physical self-concepts included sub-categories illustrating dissatisfactory appearances such as looking ill, having an overweight image and an excessively thin image. Undesirable body changes such as flaccid or sagging skin are a possible outcome of weight loss (Sarwer et al., 2011). A dramatic body transformation if often lived as a massive distortion in body image leading to body dissatisfaction (Alegría \& Larsen, 2015) and a consequent state of physical depersonalisation and feelings of unreality towards one's body (Gilmartin et al., 2013; Nascimento et al., 2013). A self-perceived image of having excessive overweight in women who had a weight loss surgery it's also associated with a sense identity-incongruence (Alegría \& Larsen, 2015).

The ii) interpersonal self-concept was mostly manifested as a positive spontaneous self-perception, which is supported by the literature that affirms improvements in one's selfconcept regarding the sense of inclusion, self-acceptance and social attachment (Castro et al., 2010; Epiphaniou \& Ogden, 2010: Gilmartin et al., 2013).

The iii) explicit personality self-concept combined as more frequently positive categorisations attributes such as calm, persistent and efficient (Goldberg, 1990; Schmukle, Back, \& Egloff, 2008). The manifested negative attributes (such as distrust/suspicion, negligence/laziness, etc.) were grouped in the frequency analysis, creating a global negative explicit personality self-concept. Sullivan, Cloninger, Przybeck and Klein (2007) in a study about personality characteristics in obesity and relation with weight loss, report that individuals with overweight demonstrated lower persistence and self-directedness when compared to lean subjects. When exploring broader identity after weight loss, Epiphaniou and Ogden (2010) demonstrate one's perspective of greater efficacy for not only weightrelated but others areas in life. 
The iv) global self-esteem, recognised as one of the most important facets of selfconcept (Baumeister, 2004; Gecas, 1982), was also one of the most commonly perceived contents. Regarding weight loss background, self-esteem is one of the most explored features of the individual (Lasikiewicz et al., 2014; Rueda-Clausen et al., 2015; van Hout et al., 2008), supporting its highlight as one of the most frequently emerged category.

Regarding the theoretical model analysed (entailing all categories mentioned by at least $10 \%$ of the participants), a three-factor model was proven to be the most suitable solution considering both literature and statistical analysis.

In the first factor — "Effective investment/Balanced self-assessment" — revealed a connection between one's investment (category "appearance and body investment" from physical self-concept), global self-esteem, the perception of being efficient (positive category of explicit personality self-concept) and the negative valence regarding personality traits.

In a qualitative and exploratory study, one's investment (body-contouring surgery) is associated not only with better physical health but also as psychological benefits such as a higher self-esteem (Gilmartin et al., 2013). This supports the present relation demonstrated between appearance and body investment and global self-esteem. In the same investigation, the perception of having accomplished efficiency in body investment is also linked with further investments - as engaging in a higher education, a new career path or more activities with family.

Designating combined attitudes — of positive and/or negative valance - and evaluations concerning the self (Crisp \& Turner, 2010; Rosenberg, 1965), the global selfesteem may be acknowledged as stable or inconsistent (Harter, 2008). Particularly regarding self-concept, specific self-esteem is attributed to domains-specific self-concept features (Baumeister, 2004; Harter, 1999). Though the finding of a positive global self-esteem may look contrary to the presence of negative explicit personality self-concept, it must be reinforced that global self-esteem translates much more than a specific self-esteem attributed to the negative personality as a specific domain; the global self-esteem in the factor "Effective investment/Balanced self-assessment" encompass the global self-concept of the individual, including the perception of efficacy and the acknowledged investment.

The second factor — "Ambivalent" — not only incorporated the ambivalent/neutral body image category, but also others opposing emergent categories related to the physical self-concept: i) negative perception of excessive weight loss and positive perception of being skinnier/less fat, and ii) negative perception of looking ill and positive perception of being healthier. Additionally, the Interpersonal positive Self-concept also prevailed in the second factor.

Both qualitative studies from Nascimento et al. (2013) and Epiphaniou and Ogden (2010) portrait a shift in one's self following weight loss; appearance distortion related to the fast and massive body transformation leads to a sense of strangeness (Gilmartin et al., 2013; Nascimento et al., 2013) that may be related with the ambivalent perception of one's physical self and, consequently, with the manifested content present in this study. In the process of psychological and emotional adaptation to the weight loss and its experience, the individual affirms significant improvements in social inclusion and interaction (Epiphaniou \& Ogden, 2010; Nascimento et al., 2013) which supports the finding of a positive interpersonal selfconcept in the present factor.

The third and last factor — "Positive acceptance/Focused" — demonstrated an association between the perceived appearance of overweight (negative physical self-concept) 


\section{SELF-CONCEPT IN WEIGHT LOSS: QUALITATIVE STUDY}

and personality attributes of calm and persistence (both positive sub-categories of explicit personality self-concept).

Contrary to the findings of Sullivan and colleagues (2007) — which stated that people with overweight showed lower persistence compared to lean participants - the present factor associated a perceived overweighed image with a positive feature of persistence. Nevertheless, it is essential to highlight that these participants weren't in weight loss process or weight loss maintenance. The participants of the present investigation not only have a record of a successfully achieved weight loss (equal or above of $7 \%$ of the initial body weight) but also have a minimum of 12 months of weight maintenance. This positive experience with weight loss might contribute to upper levels of perseverance in a weightrelated path that may not yet be completed, since one's may desire to lose more weight.

However, the already accomplished weight loss enabled the change from a life more centered on restriction, social interaction avoidance, perceived stigma, and restrict attention in one's body shape to a more liberated self with the sense of social inclusion, balanced diet routines and self-acceptance (Epiphaniou \& Ogden, 2010). With the possible long-term aspiration and goal of going further in the weight loss process, the positive feature of calm can be sustained by the acknowledgement of the accomplished success and the positive outcomes from it, which might provide tranquillity to face the path one's still wants to course.

The presented findings provide qualitative knowledge on limited literature when referring the spontaneous self-concept of the individual who achieved a successful weight loss. The inclusion of both sexes in the sample constitutes a strong-point since the present analysis represents significant content for both men and women; furthermore, a sample dimension of 30 participants is rather larger than those presented in other qualitative studies (e.g., Alegría et al., 2015; Castro et al., 2010; Epiphaniou, 2010; Gilmartin et al., 2013; Hammarström et al., 2014; Nascimento et al., 2013). Nonetheless, care must be taken when drawing inferences from the present study since its support on retrospective reflections, given the minimum of 12 months of maintenance.

Though variables of personal and context nature cannot be entirely controlled, conducting some telephone interviews has limitations since the presence of an interviewer is beneficial considering non-verbal responses and the better adaptation to the person's responses throughout the interview. However, since weight history may be considered a private theme, the telephone interviews can also be a source of comfort and provide less embarrassment when talking about it. Since the participants adopted approach to the weight loss differs (e.g., surgery, nutritional counselling) it might be beneficial to explore the individuals self-concept according to each adopted strategy, and in a possible longitudinal design in order to explore the stability of this theoretical model along the weight loss process.

The present pluralistic study — with an inter-rater reliability (Cohen's kappa $=.734$ ) — intended to explore the spontaneous self-concept on a successful weight loss through a qualitative analysis of in-depth audio-recorded interviews with both sexes. This exploration of diverse self-concept' domains - including body image - emphasises the wide variety of one's self-assessments occurring in a successful weight loss experience. This highlights that not only physical features (e.g., weight, body shape) are altered during this successful process but also psychological aspects (namely, the spontaneous self-concept) of positive and negative valences are impacted in this bodily experience. Therefore, clinical settings should considered that not only positive but also negative self-concept' representations occur during a successful weight loss process; this is important given the high weigh regain probability in 
Raquel Rosas, Filipa Pimenta, João Maroco, \& Isabel Leal

this field of biopsychosocial change. Consequently, if negative representations are attended and focused in the context of interventions there is a change that this likelihood will diminish.

\section{DECLARATION OF CONFLICTING INTERESTS}

The authors declare that there is no conflict of interest.

\section{ACKNOWLEDGMENTS}

This work was supported by FCT - Portuguese Foundation for Science and Technology under Grant SFRH/BD/32359/2006 and Grant UID/PSI/04810/2013.

\section{REFERENCES}

Alipoor, S., Goodarzi, A. M., Nezhad, M. Z., \& Zaheri, L. (2009). Analysis of the relationship between physical self-concept and body image dissatisfaction in female students. Journal of Social Sciences, 5, 60-66. DOI: org/10.3844/jssp.2009.60.66

Anderson, J. W., \& Konz, E. C. (2001). Obesity and disease management: Effects of weight loss on comorbid conditions. Obesity Reviews, 9, 326-334. DOI: org/10.1038/oby.2001.138

Annesi, J. J., \& Porter, K. J. (2015). Reciprocal effects of exercise and nutrition treatmentinduced weight loss with improved body image and physical self-concept. Behavioral Medicine, 41, 18-24. DOI: org/10.1080/08964289.2013.856284

Annis, N. M., Cash, T. F., \& Hrabosky, J. I. (2004). Body image and psychosocial differences among stable average weight, currently overweight, and formerly overweight women: The role of stigmatizing experiences. Body Image: An International Journal of Research, 1, 155-167. DOI: org/10.1016/j.bodyim.2003.12.001

Asendorpf, J. B., Banse, R., \& Mücke, D. (2002). Double dissociation between implicit and explicit personality self-concept: The case of shy behaviour. Journal of Personality and Social Psychology, 83, 380-393. DOI: org/10.1037/0022-3514.83.2.380

Bardin, L. (1977). Análise de Conteúdo (Edição revista e actualizada). Lisboa: Ed. 70

Baumeister, R. F. (2004). Self-concept, self-esteem, and identity. In V. J. Derlenga, B. A. Winstead, \& W. H. Jones ( $3^{\text {rd }}$ Ed.), Personality: contemporary theory and research (pp. 246280). Cengage Learning.

Baumeister, R. F. (2010). The self. In R. F. Baumeister, \& E. J. Finkel (Eds.), Advanced social psychology: The state of the science (pp. 139-175). Oxford: Oxford University Press.

Binkley, S. E., Fry, M. D., \& Brown, T. C. (2009). The relationship of college students' perceptions of their BMI and weight status to their physical self-concept. American Journal of Health Education, 40(3), 139-145.

Braun, V., \& Clarke, V. (2006). Using thematic analysis in psychology. Qualitative Research in Psychology, 3, 77-101. DOI: org/10.1191/1478088706qp063oa

Cash, T. F. (2011). Crucial considerations in the assessment of body image. In T. F. Cash, \& L. Smolak ( $2^{\text {nd }}$ Ed.), Body image: A handbook of science, practice, and prevention (pp. 369377). New York: Guilford Press.

Cash, T. F., \& Pruzinsky, T. (2004). Body Image: A Handbook of theory, research, and clinical practice. New York: Guilford Press. 


\section{SELF-CONCEPT IN WEIGHT LOSS: QUALITATIVE STUDY}

Cash, T. F., Melnyk, S. E., \& Hrabosky, J. I. (2004). The assessment of body image investment: An extensive revision of the appearance schemas inventory. International Journal of Eating Disorders, 35(3), 305-316. DOI: org/10.1002/eat.10264

Castro, M. R, Carvalho, R. S., Ferreira, V. N., \& Ferreira, M. E. C. (2010). Função e imagem corporal: uma análise a partir do discurso de mulheres submetidas à cirurgia batriátrica. Revista Brasileira Ciência. Esporte, 32(2-4), 167-183.

Cohen, J. (1960). A coefficient of agreement for nominal scales. Educational and Psychological Measurement, 20, 37-46. DOI: org/10.1177/001316446002000104

Crandall, C., \& Biernat, M. (1990). The ideology of anti-fat attitudes. Journal of Applied Social Psychology, 20(3), 227-243.

Crisp, R. J., \& Turner, R. N. (2010). Essential social psychology.(2 ${ }^{\text {nd }}$ Ed.). Sage Publications.

Epiphaniou, E., \& Ogden, J. (2010). Successful weight loss maintenance and a shift in identity from restriction to a new liberated self. Journal of Health Psychology, 15, 887-896. DOI: org/10.1177/1359105309358115

Fabricatore, A. N., Wadden, T. A., Higginbotham, A. J., Faulconbridge, L. F., Nguyen, A. M., Heymesfield, S. B., \& Faith, M. S. (2011). Intentional weight loss and changes in symptoms of depression: a systematic review and meta-analysis. International Journal of Obesity, 35, 1363-1376. DOI: org/10.1038/ijo.2011.2

Gecas, V. (1982). The self-concept. Annual Review of Sociology, 8, 1-33.

Gilmartin, J., Long, A., \& Soldin, M. (2013). Identity transformation and a changed lifestyle following dramatic weight loss and body-contouring surgery: An exploratory study. Journal of Health Psychology, 0, 1-10. DOI: org/10.1177/1359105313511838

Gorin, A. A., Pinto, A. M., Tate, D. F., Raynor, H. A., Fava, J. L., \& Wing, R. R. (2007). Failure to meet weight loss expectations does not impact maintenance in successful weight losers. Obesity, 15(12), 3086-3090. DOI: org/10.1038/oby.2007.367

Hammarström, A., Wiklund, A. F., Lindahl, B., Larsson, C., \& Ahlgren, C. (2014). Experiences of barriers and facilitators to weight-loss in a diet intervention - a qualitative study of women in Northern Sweden. BioMed Central Women's Health, 14(1).

Harris, M. B., Harris, R. J., \& Bochner, S. (1982). Fat, four-eyed, and female: Stereotypes of obesity, glasses, and gender. Journal of Applied Social Psychology, 12, 503-516. DOI: org/10.1111/j.1559-1816.1982.tb00882.x

Harter, S. (1999). The content, valence, and organization of self-evaluative judgments. In S. Harter (Eds.), The Construct of the Self (pp.116-141). New York: The Guilford Press.

Harter, S. (2008). The developing self. In W. Damon, R. M. Lerner, D. Kuhn, R. S. Siegler, $\&$ N. Eisenberg (Eds.), Child and adolescent development: An advanced course (pp. 216255). New Jersey: John Wiley \& Sons, Inc.

Hebl, M. R., \& Mannix, L. M. (2003). The weight of obesity in evaluating others: A mere proximity effect. Personality and Social Psychology Bulletin, 29, 28-38. DOI: org/10.1177/0146167202238369

Institute of Medicine. (1995). Weighing the options: Criteria for evaluating weight management programs. Washington, DC: Government Printing Office.

Jung, J., Forbes, G. B., \& Chan, P. (2010). Global body and muscle satisfaction among college men in the United States and Hong Kong-China. Sex Roles, 63, 104-117. DOI: org/10.1007/s11199-010-9760-z 
Knowler, W. C., Barrett-Conner, E., Fowler, S. E., Hamman, R. F., Lachin, J. M., Walker, E. A., Nathan, D. M. (2002). Reduction in the incidence of type 2 diabetes with lifestyle intervention or metformin. New England Journal of Medicine, 346, 393-403. DOI: org/10.1056/NEJMoa012512

Lasikiewicz, N., Myrissa, K., Hoyland, A., \& Lawton, C. L. (2014). Psychological benefits of weight loss following behavioural and/or dietary weight loss interventions. A systematic research review. Apetite, 72, 123-137. DOI: org/10.1016/j.appet.2013.09.017

Linville, P. W. (1985). Self-complexity and affective extremity: Don't put all of your eggs in one cognitive basket. Social Cognition, 3, 94-120. DOI: org/10.1521/soco.1985.3.1.94

Marčič, R., \& Grum, D. K. (2011). Gender differences in self-concept and self-esteem components. Studia Psychologica, 53(4), 373-383.

Markus, H. (1977). Self-schemata and processing information about the self. Journal of Personality and Social Psychology, 35, 63-78. DOI: org/10.1037/0022-3514.35.2.63

McHugh, M. L. (2012). Interrater reliability: the kappa statistic. Biochemia Medica, 22, 276282. DOI: org/10.11613/BM.2012.031

Murnen, S. K. (2011). Gender and body images. In T. F. Cash, \& L. Smolak (2 ${ }^{\text {nd }}$ Ed.), Body image: A handbook of science, practice, and prevention (pp. 173-179). New York: The Guilford Press.

Nascimento, C. A. D., Bezerra, S. M. M., \& Angelim, E. M. S. (2013). Vivência da obesidade e do emagrecimento em mulheres submetidas à cirurgia bariátrica. Estudos de Psicologia, 18(2), 193-201.

Ogden, J., \& Clementi, C. (2010). The experience of being obese and the many consequences of stigma. Journal of Obesity, 2010, 1-10. DOI: org/10.1155/2010/429098

Oyserman, D., Elmore, K., \& Smith, G. (2012). Self, self-concept, and identity. In M. R. Leary, \& J. P. Tangney ( $2^{\text {nd }}$ Ed.), Handbook of self and identity (pp. 69-104). New York: The Guildford Press.

Pritchard, M. E. (2014). Do body image investment and evaluation relate to bulimic symptoms in U.S. collegiate men and women in the same way? Psychology of Men \& Masculinity, 15, 163-169. DOI: org/10.1037/a0032835

Rojas, C., Brante, M., Miranda, E., \& Pérez-luco, R. (2011). Descripción de manifestaciones ansiosas, depresivas y autoconcepto en pacientes obesos mórbidos, sometidos a cirugía bariátrica. Revista Médica de Chile, 139(5), 571-578.

Rosenberg, M. (1965). Society and the adolescent self-image. Princeton, NJ: Princeton University Press.

Rueda-Clausen, C. F., Ogunleye, A. A., \& Sharma, A. M. (2015). Health benefits of longterm weight-loss maintenance. Annual Review of Nutrition, 35, 475-516. DOI: org/10.1146/annurev-nutr-071714-034434

Sarwer, D. B., Dilks, R. J., \& Spitzer, J. C. (2011). Weight loss and changes in body image. In T. F. Cash, \& L. Smolak ( $2^{\text {nd }}$ Ed.), Body image: A handbook of science, practice, and prevention (pp. 369-377). New York: The Guilford Press.

Schmukle, S. C., Back, M. D., Egloff, B. (2008). Validity of the five-factor model for the implicit self-concept of personality. European Journal of Psychological Assessment, 24, 263 272. DOI: org/10.1027/1015-5759.24.4.263

Schunk, D. H., \& Pajares, F. (2009). Self-efficacy theory. In K. R. Wentzel \& A. Wigfield (Eds.), Handbook of motivation at school (pp. 35-54). New York: Routledge. 


\section{SELF-CONCEPT IN WEIGHT LOSS: QUALITATIVE STUDY}

Shavelson, R. J., \& Bolus, R. (1982). Self-concept: The interplay of theory and methods. Journal of Educational Psychology, 74(1), 3-17. DOI: org/10.1037/0022-0663.74.1.3

Stroebe, W. (2008). Dieting, overweight, and obesity: Self-regulation in a food-rich environment. (Eds.). Washington: American Psychological Association.

Sullivan, S., Cloninger, C. R., Przybeck, T. R., \& Klein, S. (2007). Personality characteristics in obesity and relationship with successful weight loss. International Journal of Obesity, 31, 669-674.

Van Hout, G. C. M., Fortuin, F. A. M., Pelle, A. J. M., \& van Heck, G. L. (2008). Psychosocial functioning, personality, and body image following vertical banded gastroplasty. Obesity Surgery, 18, 115-120. DOI: org/10.1007/s11695-007-9309-6

Vidal, J. (2002). Updated review on the benefits of weight loss. International Journal of Obesity, 26, 25-28. DOI: org/10.1038/sj.ijo.0802215

Wing, R. R., \& Hill, J. O. (2001). Successful weight loss maintenance. Annual Review of Nutrition, 21, 323-341. DOI: org/10.1146/annurev.nutr.21.1.323

Wing, R. R., Lang, W., Wadden, T. A., Safford, M., Knowler, W. C., Bertoni, A. G., Hill, J. O., Brancati, F. L., Peters, A., \& Wagenknecht, L. (2011). Benefits of modest weight loss in improving cardiovascular risk factors in overweight and obese individuals with type 2 diabetes. Diabetes Care, 34, 1481-1486. DOI: org/10.2337/dc10-2415

World Health Organization. (2015). Obesity and Overweight (Fact sheet n⿳311). Retrieved from http://www.who.int/mediacentre/factsheets/fs311/en. 